\section{Monitoring the freezing point of buffalo milk}

\author{
Antonella Pesce, Caterina Salzano, \\ Anna De Felice, Francesca Garofalo, \\ Salvatore Liguori, Annunziata De Santo, \\ Pierpaolo Palermo, Achille Guarino \\ Institute for Experimental Veterinary \\ Medicine of Southern Italy, Caserta, Italy
}

\begin{abstract}
The aim of this study was to evaluate the basic freezing point of buffalo milk. Bulk milk samples were collected from buffalo and cattle farms in Caserta area from 2008 to 2014. The analysis involved a total of 1886 buffalo milk samples and 1711 bovine milk samples. These were also tested for fat, protein and lactose contents by means of infrared spectrometry. The freezing point was determined by means of a thermistor cryoscope. Data underwent statistical analysis. Our research showed an average freezing point of $-0.528^{\circ} \mathrm{C}$ for buffalo milk and $0.522^{\circ} \mathrm{C}$ for bovine milk. Given the lack of data on the freezing point of buffalo milk, our study provides the first indication of a basic freezing point of the milk of this species in Italy.
\end{abstract}

\section{Introduction}

The freezing point of milk, which is an important indicator of its quality, is determined by its composition. As the freezing point of bovine milk is fairly constant, the freezing point of bulk tank milk is used to determine whether water has been added. The average freezing point of raw bovine milk is between 0.522 and $-0.540^{\circ} \mathrm{C}$ (Fox and McSweeney, 1998). In bulk tank milk studies, a freezing point of $-0.528^{\circ} \mathrm{C}$ has been found in Poland (Kuczaj, 2001) and Italy (Coni et al., 1997) and of $-0.5209^{\circ} \mathrm{C}$ in the Netherlands (Slaghuis, 2001; Navrátilová et al., 2006). In Egypt, the freezing point of buffalo milk ranges from -0.552 to $-0.558^{\circ} \mathrm{C}$ (Hofi et al., 1966) and the regulatory standard ranges from -0.530 to $-0.560^{\circ} \mathrm{C}$ (Egyptian Organization for Standardization and Quality, 2005).

Until 2004, in compliance with EU legislation (Council 92/46 92/47/EEC Directive of 16 June 1992, incorporated into Italian law by DPR 54/1997; European Commission, 1992a, 1992b; Italian Republic, 1997), the maximum permitted freezing point of both raw and heattreated drinking milk was $\leq-0.520^{\circ} \mathrm{C}$ : above this level, it was supposed to add water to cow's milk. In accordance with EC Regulation
$\mathrm{N}^{\circ} 1234 / 07$ (European Commission, 2007), milk produced for human consumption must have a freezing point close to the mean freezing point recorded in raw milk in the original area of production. However, EC regulation $\mathrm{N}^{\circ} 852$ and 853/2004 (European Commission 2004a, 2004b) makes no mention of the freezing point, which remains an index of the quality of raw milk. Indeed, processors use the freezing point as a quality criterion for calculating the price of raw milk purchased and processed into dairy products.

Today, although the basic freezing point of cow's milk is clearly known in Italy (Lombardi et al., 1998) and in other countries (Navrátilová et al., 2006), there are no data on the basic freezing point of buffalo milk. The aim of the present research was to determine the basic freezing point of buffalo milk by collating and evaluating the data from analyses carried out from 2008 to 2014.

Milk samples were collected from 60 buffalo farms. As the samples analysed were collected exclusively for the purpose of the project, they were taken only from farms that adopted particular precautions to avoid the presence of water residues in their tanks and which did not add water to their milk. Variability in the freezing point of buffalo and bovine milk from 2008 to 2014 was also evaluated.

\section{Materials and Methods}

The samples were collected from buffalo farms in the Caserta area from 2008 to 2014. Bulk milk samples were transported to the laboratory of the Institute for Experimental Veterinary Medicine of Southern Italy at $4^{\circ} \mathrm{C}$. The analysis involved a total of 1886 buffalo milk samples collected from 60 farms and 1711 bovine milk samples collected from 40 farms. All samples were analysed for $\mathrm{pH}$ and fat, protein, lactose and lactic acid contents; $\mathrm{pH}$ was measured at $20^{\circ} \mathrm{C}$, usually $1 \mathrm{~h}$ after the samples had arrived at the laboratory.

The chemical composition of the milk samples - milk fat ( $\% \mathrm{w} / \mathrm{v})$, crude protein ( $\% \mathrm{w} / \mathrm{v})$ and lactose anhydride (\% w/v) - was determined by means of the infrared spectrometric method (IDF, 2013), using a Milkoscan FTplus instrument (Foss Electric, Hillerød, Denmark). In accordance with Italian law (Ministerial Decree 26/03/92; Italian Republic, 1992), the freezing point of milk was measured by means of a thermistor cryoscope: Advanced Cryoscope (Advanced Instruments, Norwood, MA, USA). These instruments are commonly used for parametric measurements in dairy analyses (Sánchez et al., 2007) and the whole process is carried out under standard quality control.

Statistical analysis was performed by means
Correspondence: Antonella Pesce, Institute for Experimental Veterinary Medicine of Southern Italy, via A. Jervolino 19,81100 Caserta, Italy. Tel: +39.0823 .388241 - Fax: +39.0823 .386766 .

E-mail: antonella.pesce@cert.izsmportici.it

Key words: Freezing point; Milk; Buffalo.

Conflict of interest: the authors declare no potential conflict of interest.

Received for publication: 18 December 2015 .

Revision received: 19 February 2016.

Accepted for publication: 23 February 1016.

This work is licensed under a Creative Commons Attribution-NonCommercial 4.0 International License (CC BY-NC 4.0).

(C) Copyright A. Pesce et al., 2016

Licensee PAGEPress, Italy

Italian Journal of Food Safety 2016; 5:5691

doi:10.4081/ijfs.2016.5691

of IBM SPSS ${ }^{\circledR} 21$ (Statistical Package for Social Science, version 21 for Windows; IBM Corporation, New York, NY, USA).

\section{Results and Discussion}

The freezing point was determined only in samples that displayed the composition shown in Table 1. The basic freezing point of buffalo milk was lower than that of cow's milk; statistical analysis of all data in the years 2008-2014 showed an average value of $-0.528^{\circ} \mathrm{C}$ for buffalo milk and an average value of $-0.522^{\circ} \mathrm{C}$ for cow's milk. Figure 1 shows box-and-whisker plots for buffalo milk samples collected over the 5 years. The central line indicates the median level and the boxes represent the first and third quartiles, while the whiskers are set to \pm 1.5 times the inter-quartile interval. These levels should match the minimum and the maximum levels in the absence of outliers and/or extreme levels. From 2008 to 2014, the percentage of samples with a value in excess of the gold point of $-0.520^{\circ} \mathrm{C}$ declined from 35 to $6 \%$ for buffalo milk and from 35 to $5.4 \%$ for bovine milk). Focusing on last year 2014, 125 buffalo milk samples collected from 60 farms displayed an average freezing point -0.536 \pm 0.0091 (standard deviation), with a $95 \%$ confidence interval from -0.534 to -0.537 ; the average of the samples analysed was significantly different $(\alpha=5 \%)$ from $\mu=-0.520$ (Table 2).

\section{Conclusions}

In our study, the basic freezing point of buf- 
falo milk proved to be lower than that of bovine milk; this could be explained by the fact that buffalo milk has a higher content of non-fat solids, fat, protein and some mineral salts (Zicarelli, 2001; Masud et al., 1992).

Our data analysis showed that the percentage of both bovine and buffalo samples with a freezing point value higher than $-0.520^{\circ} \mathrm{C}$ decreased over the years considered. This suggests that the percentage of frauds (adding water to bulk milk tanks to increase the volume) decreased. However, other factors also affect the freezing point of both buffalo and cow milk, such as the breed of the animals, stage of lactation, season, feed, water intake, climate, mastitis, and storage time and temperature. Furthermore, differences between morning and evening milkings have also been reported (Slaghuis, 2001).

When milking machines are cleaned, a small quantity of rinsing water may be retained. Thus, some water will be present in milk samples if the milking machine and/or storage tank have not been properly dried after cleaning and sterilisation. It could therefore be hypothesised that in the period considered the reduction in the percentage of samples with a freezing point value above $-0.520^{\circ} \mathrm{C}$ may have been due to a more careful drying on the part of the producers.

As about $80 \%$ of buffaloes in Italy are concentrated in Campania region (Tufarelli et al., 2008; Zicarelli, 2001), the present study yields representative data and provides the first indication of the basic freezing of point buffalo milk.

Table 1. Composition of buffalo milk tested (\%).

\begin{tabular}{lcccc} 
& Fat & Proteins & Lactose & Lactic acid \\
Mean value & 8.30 & 4.70 & 4.80 & $<0.18$ \\
Range & $8.00-8.60$ & $4.50-4.90$ & $4.60-5.00$ & - \\
\hline
\end{tabular}

Table 2. Descriptive statistics and T_Test.

\begin{tabular}{|c|c|c|c|c|c|c|}
\hline \multirow{2}{*}{\multicolumn{2}{|c|}{$\begin{array}{c}\text { Descriptive statistics } \\
\text { No. }\end{array}$}} & \multicolumn{5}{|c|}{ T_Test $\mu=-0.520\left({ }^{\circ} \mathrm{C}\right)$} \\
\hline & & Mean & SD & Df & Sig. (2-sided) & Mean difference \\
\hline Freezing point & 125 & -0.536 & .009 & 124 & .000 & -.016 \\
\hline
\end{tabular}

$\mathrm{SD}$, standard deviation; df, degree of freedom.

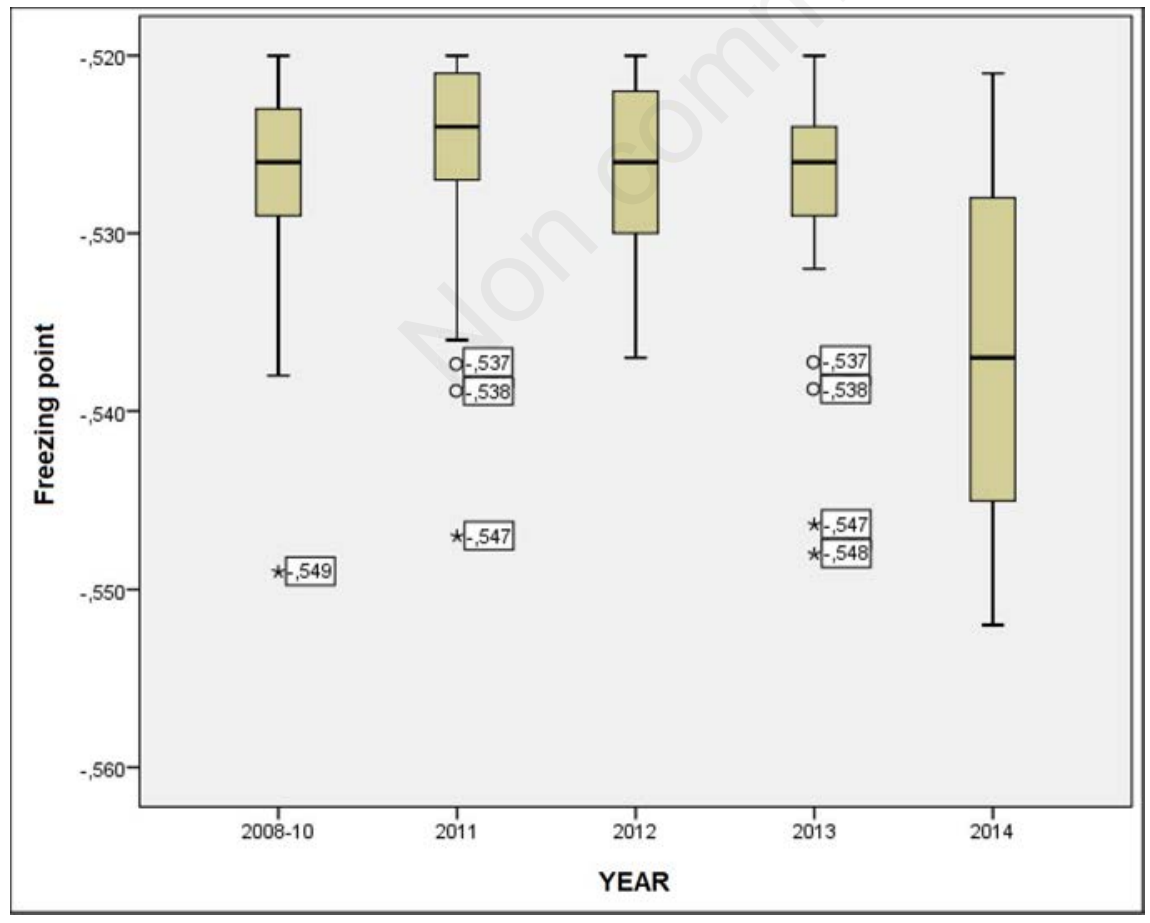

Figure 1. Box-and-whisker plots of median freezing point values $(95 \% \mathrm{CI})$ for buffalo milk in different years with evidence of outliers $(O=1.5$ times the inter-quartile range) and extreme values $(*=3$ times the inter-quartile range).

\section{References}

Coni E, Di Pasquale M, Fava L, Bocca A, 1997. A pilot survey on the freezing point of raw and heat-treated Italian milk. Ital J Food Sci 9:239-48.

Egyptian Organization for Standardization and Quality, 2005. Egyptian standards 1541/2005: milk and milk products, part 1: raw milk. Egyptian Organization for Standardization and Quality, Cairo, Egypt.

European Commission, 1992a. Council Directive of 16 June 1992 laying down the health rules for the production and placing on the market of raw milk, heat-treated milk and milk-based products, 92/46/EEC. In: Official Journal, L 268/1, 14/09/1992.

European Commission, 1992b. Council Directive of 16 June 1992 on the conditions for granting temporary and limited derogations from specific Community health rules on the production and placing on the market of milk and milk-based products, 92/47/EEC. In: Official Journal, L 268/33, 14/09/1992.

European Commission, 2004a. Regulation of the European Parliament and of the Council of 29 April 2004 laying down specific hygiene rules for food of animal origin, 853/2004/CE. In: Official Journal, L $139 / 55,30 / 04 / 2004$.

European Commission, 2004b. Regulation of the European Parliament and of the Council of 29 April 2004 on the hygiene of foodstuffs, 852/2004/CE. In: Official Journal, L 139/1, 30/04/2004.

European Commission, 2007. Council Regulation of 22 October 2007 establishing a common organisation of agricultural markets and on specific provisions for certain agricultural products (Single CMO Regulation), 1234/2007/EC. In: Official Journal, L 299/1, 16/11/2007.

Fox PF, McSweeney PLH, 1998. Dairy chemistry and biochemistry. Blackie Academic \& Professional, London, UK.

Hofi AA, Rifaat ID, Khorshid MA, 1966. Studies on some physicochemical properties of Egyptian buffaloes and cows' milk. Indian J Dairy Sci 19:113-7.

IDF, 2013. International standards. Milk and liquid milk products. Guidelines for the application of mid-infrared spectrometry. Lait et produits laitiers liquids. Lignes directrices pour l'application de la spectrométrie dans le moyen infrarouge. International Dairy Federation, Brussels, Belgium.

Italian Republic, 1992. Ministerial Decree of 26/03/1992 realizing decision no. n. 91/180/CEE laying down certain methods of analysis and testing of raw milk and heat-treated milk. In: Official Journal, 
General Series n. 90, 16/04/1992, Ordinary Supplement n. 67.

Italian Republic, 1997. Ministerial Decree of 14/01/1997 for producing and putting on the market milk and its derivatives. In: Official Journal, General Series n. 59, 12/03/1997, Ordinary Supplement n. 54.

Kuczaj M, 2001. Interrelations between year season and raw milk hygienic quality indices. Available from: http:/www.ejpau. media.pl/volume4/issue1/animal/art01.html

Lombardi G, Arrigoni N, Calamari L, Stefanini L, 1998. Ricerche su talune cause di variazione del punto crioscopico nel latte di bovine di razza Frisona Italiana. Available from: www.buiatria.it/file_30/Pages\% 20from\%20volume30-17.pdf

Masud T, Athar IH, Shah MA, 1992. Comparative study on paneer making from buffalo and cow milk. Asian-Austral J Anim Sci 5:563-5.

Navrátilová P, Janštová B, Glossová P, Vorlová L, 2006. Freezing point of heat-treated drinking milk in the Czech Republic. Czech J Food Sci 24:156-63.

Sánchez A, Sierra D, Luengo C, Corrales JC, de la Fe C, Morales CT, Contreras A, Gonzalo CJ, 2007. Evaluation of the MilkoScan FT 6000 milk analyzer for determining the freezing point of goat's milk under different analytical conditions. Dairy Sci
90:3153-61.

Slaghuis BA, 2001. The freezing point of authentic and original farm bulk tank milk in the Netherlands. Int Dairy J 11:121-6.

Tufarelli V, Dario M, Laudadio V, 2008. Diet composition and milk characteristics of Mediterranean water buffaloes reared in Southeastern Italy during spring season. Available from: http://www.lrrd.org/ Irrd20/10/tufa20165.htm

Zicarelli L, 2001. La bufala mediterranea italiana: esempio di una razza autoctona in espansione. Scienza e Tecnica Lattiero Casearia 52:279-84. 